\title{
THE REAL SECTOR OF ECONOMY: FACTORS AND TRENDS IN JULY 2013
}

\author{
O.Izryadnova
}

In July 2013, the industrial production index stood at $99.3 \%$ in annual terms, including $98.5 \%$ in the manufacturing industry, and $100.4 \%$ in the mineral extraction sector. Slower growth rates in exports of traditional raw commodities and related refinery products made Russian economic growth rates even slower. Index of output of products and services in terms of basic types of economic activity remained within a positive values range in July 2013 vs. July 2012, because agricultural production increased by 5.8\%, retail sales turnover by 4.3\%, and paid retail services by $2.7 \%$. Labor costs and physical resources kept growing against weakened competitive power and cost-effectiveness of the Russian economy.

In the period of January thru July 2013, industrial production figures remained at the same period level of the previous year. However, capital investments contracted by $0.7 \%$, volume of works in the construction sector declined by $0.3 \%$, and provision of transport services declined by $0.9 \%$ as compared to the same period of last year. During the same period, the index of output of products and services by type of economic activity stood at $100.3 \%$ through an increase of $3.1 \%$ in agricultural production, $3.8 \%$ and $1.0 \%$ in retail and wholesale trade turnover, and $2.1 \%$ in paid retail services against January-July 2012.

During January over July 2013, economic growth was adversely affected by a $12.6 \%$ contraction in net exports year-on-year, according to preliminary data of the Central Bank of Russia. The trend towards outstripping growth rate of imports over exports resumed in the Russian economy in Q2 2013. Exports growth rates have been slowing down by cost in annual terms over the past three quarters, thereby intensifying the trend towards slower growth rates in the Russian economy.

Import growth rates slowed down from $106.3 \%$ in Q1 2013 to $102.8 \%$ in Q2 2013 as compared to the same periods of last year. Imports kept playing an important role in building up resources in the economy against slow dynamics of domestic production output. At the same time, some changes occurred in the structure of imports - the share of investment and consumer products has been reducing against increased role of intermediate demand products. The share of imports in retail sales turnover remained at $44 \%$, which was the average in 2012.

The structure of domestic demand was heavily influenced by a three-month fall of annual growth rates in the manufacturing industry. During January over July 2013 , the manufacturing index stood at $99.8 \%$, whereas in July 2013 it was $98.5 \%$ as compared to the same periods of last year.
Sectoral differentiation kept developing in the manufacturing industry. Consumer products manufacturing saw a consistent growth in food production as well as textile and ferment production output. Chemical production, production of rubber goods, and oil products kept leading in the segment of intermediate demand products.

A weaker demand had an adverse effect on the dynamics of mid-tech and high-tech production facilities in machine building and metallurgical sectors. During January over July, machinery and equipment production dropped by $7.1 \%$ year-on-year to determine a sluggish growth in production of electrical equipment, electronic and optical equipment which supplies end-demand machine building production facilities. Production index of transport means and equipment stood at $98.7 \%$ during January over July 2013 , including motorcars (97.4\%), motortrucks (93.2\%), and busses $(96.8 \%)$ as compared to the same period of last year. It should be noted that import volumes increased by $16.6 \%$ as motorcar production dropped in $\mathrm{H} 12013$.

A big comparative base should be emphasized as one the factors which determine slowdown rates in the machine-building industry, because H1 2012 saw significant growth rates in production in this industry; decline in the effective demand, and capital investments; weaker customs and tariff protection of the domestic market in response to the accession to the WTO; inefficiency of certain types of Russia-made equipment, machinery and motor vehicles vs. imported products of similar type.

For the purposes of supporting the domestic car market, the Ministry of Industry and Trade of the Russian Federation from 01.072013 launched a program on government support to easy-term car loans and established the rules for the allocation of federal budget subsidies to Russian credit organizations to compensate for losses in revenues from retail car loans Issued by Russian credit institutions in 2013-2014. 
Weakening in the demand for metals on the side of machine building and construction industries accelerated slowdown rates in the metal production sector. Metallurgical production output over the first seven months and in July 2013 stood at $98.6 \%$ and $93.9 \%$ against January-July and July 2012 respectively, and production of ready-made metal products at $97.9 \%$ and $92.3 \%$.

The non-ferrous metal market has been facing a hard challenge this year. During January over July 2013, the non-ferrous metal production index stood at $96.9 \%$ yearon-year, which was caused first of all by decreased export supplies with regard to almost all basic items. From the middle of Q1 2013 global prices of basic non-ferrous metals went down to reach the bottom by July 2013. Stock levels were increasing thought the entire period. Weakening in the domestic and external demand let to revision of production and investment programs. Decrease in consumption volumes in the domestic market and dynamics of export sales volumes predetermined changes in the output structure of Russian aluminum smelters through growth in more expensive and costefficient aluminum casting alloys. Production of primary aluminum alloys during January over July 2013 increased $6.4 \%$ against January-July 2012 against a 10.5\% decline in primary aluminum output. Primary aluminum production decreased first of all at non-competitive facilities of aluminum smelters whose costs, given payment of interest on loans, exceeded monthly average global prices of primary aluminum. RUSAL Board of Directors considered and approved on August 15, 2013 a long-term program of stage-wise shut-down of inefficient production facilities. Inefficient production facilities will be restructured for production of aluminum alloys and products of other types.

Growth in mineral extraction (0.9\%), production of fossil fuels $(0.8 \%)$, and other types of minerals (1.7\%) was one of the factors which maintained industrial production growth rates in 2013 at the level of January-July 2012. During January over July 2013, crude oil production volume increased by $0.7 \%$ while the share of crude oil refining in total crude oil production increased up to $52.9 \%$ against $51.9 \%$ in the same period of 2012. Index of oil product production during January over July 2013 stood at $103.1 \%$ year-on-year, including $104.8 \%$ in July 2013.

Gas production contracted $0.4 \%$ year-on-year during January over July 2013, except for July, when it increased $2.9 \%$ year-on-year in response to higher demand for the Russian gas in European countries.

Domestic market dynamics was supported by growth in retail sales turnover and paid retail services. However, growth rates in consumer demand were less than a half of the last year values. Q2 2012 saw a downtrend in non-food market turnover and paid retail services. Non-food market turnover gained 5.3\% during January over July 2013 against 9.1\% in the preceding period.

Households consumer behavior experienced some changes: propensity to save was increasing, whereas the share of expenses on purchase of goods declined. Consumer demand dynamics was heavily influenced by an uptrend in real disposable income during January over July 2013 (4.3\% against $2.7 \%$ in the preceding year), real wages $(5.5 \%$ against $10.4 \%$ in the preceding year) and real volume of granted pensions (2.6\% against $5.5 \%$ in the preceding year). In addition, the retail sector saw a steadily high borrowing level. Retail loans increased by 33.8\% against July 2012.

Analysis of the current situation shows that a trend towards deterioration of the real sector of economy has been accompanied by accelerated growth in real household income and real wages. This has been accompanied by a heavier load upon budgets in the social security sector and weaker resource efficiency and competitive power in the real sector of economy.

In H1 2013, the financial performance result of enterprises and organizations (profit and loss balance) accounted for $77.1 \%$ of the same indicator registered in $\mathrm{H} 12012$, and cost-effectiveness of sold goods deteriorated from $10.0 \%$ to $7.7 \%$. Manufacturing industry's financial performance result deteriorated by $28.5 \%$ against H1 2012, having impaired cost-effectiveness down to $9.1 \%$ against $11.3 \%$ in the preceding year. Such developments as growth in labor costs, costs of logistics and cargo transportation, cost of electricity should be emphasized as domestic factors which have been weakening cost-effectiveness in production this year. The situation has been deteriorated through changes in external demand for and prices of exported Russian goods.

Dynamics of the principal macro indicators allows one to note that regardless of slowdown in economic dynamics and growth in labor costs, the situation in the labor market remained stable in July 2013. Employment of economically active population was maintained at the average level of 2012 and amounted to 71.8 million persons. In $\mathrm{H} 12013$, the number of employees by comparable range of organizations remained unchanged against a significant redistribution of workers from the real sector of economy to the trade and market services sector. Unemployment rate, as calculated by the ILO methodology, stood at 5.3\% of economically active population (4 million persons), corresponding to the level of July 2012. During June over July 2013 the need in workforce weakened for the first time in the year and amounted to 1.8 million job vacancies as of end of July, having no adverse ef- 
Table 1

BALANCED FINANCIAL RESULT AND COST-EFFECTIVENESS BY TYPE OF ECONOMIC ACTIVITY IN H1 2013

\begin{tabular}{|c|c|c|c|c|c|}
\hline & bal & $\begin{array}{l}\text { fit }(+) \text { and } \\
\text { as perce }\end{array}$ & & $\begin{array}{l}\text { Cost-eff } \\
\text { sold goo } \\
\text { work }\end{array}$ & $\begin{array}{l}\text { eness of } \\
\text { oroducts, } \\
\text { rvices }\end{array}$ \\
\hline & Q1 2012 & Q2 2012 & H1 2012 & H1 2012 & H1 2013 \\
\hline Total & 70.9 & 84.6 & 77.1 & 10.0 & 7.7 \\
\hline $\begin{array}{l}\text { of which: } \\
\text { agricultural sector, hunting and forestry }\end{array}$ & 44.4 & 78.7 & 61.3 & 13.6 & 6.3 \\
\hline fishing, fish farming & 63.9 & 116.2 & 68.7 & 24.8 & 20.8 \\
\hline mineral resources extraction & 88.8 & 96.2 & 92.4 & 30.5 & 26.8 \\
\hline $\begin{array}{l}\text { including: } \\
\text { production of fossil fuels }\end{array}$ & 92.0 & 98.6 & 95.2 & 27.7 & 25.7 \\
\hline manufacturing industry & 62.2 & 82.2 & 71.5 & 11.3 & 9.1 \\
\hline $\begin{array}{l}\text { electric power, gas and water pro- } \\
\text { duction and distribution }\end{array}$ & 96.8 & 29.2 & 89.1 & 5.4 & 5.3 \\
\hline construction industry & 38.5 & 51.0 & 49.1 & 2.0 & 2.7 \\
\hline $\begin{array}{l}\text { wholesale and retail trade; } \\
\text { repair of motor vehicles, } \\
\text { motorbikes, household appliances } \\
\text { and personal demand items }\end{array}$ & 76.2 & 70.1 & 73.3 & 8.7 & 6.9 \\
\hline transports and communication & 58.1 & 124.5 & 83.0 & 14.0 & 10.9 \\
\hline $\begin{array}{l}\text { of which: } \\
\text { railway transport operations }\end{array}$ & 35.0 & 30.5 & 33.4 & 8.8 & 3.4 \\
\hline pipeline transportation & 65.2 & 132.6 & 85.5 & 18.3 & 15.9 \\
\hline communications & 77.4 & 157.1 & 108.4 & 28.0 & 29.3 \\
\hline financial business & 60.2 & - & 24.1 & 0.5 & 0.2 \\
\hline
\end{tabular}

Source: Rosstat..

fect on the tension coefficient in the labor market. The tension coefficient was 60.6 persons per 100 available vacancies in July 2013 (against 72 persons in the same period of 2012).

Growth in part-time employment should be taken into account in assessing the situation in the labor market. In Q2 2013, part-time employment initiated by the employer or under agreement between the employee and the employer accounted for $2.1 \%$ of the manning table at organizations (net of small-sized business entities). The biggest part-time employment was noted in organizations manufacturing means of transportation and equipment (part-time workers and those who remained idle accounted for $8.3 \%$ of the manning table), at federal railway transport organizations (9.5\%), in hotels and restaurants (8.1\%). B metallurgical production and production of ready-made metal products, production of machinery and equipment, production of means of transportation and equipment - workers who were on self-initiated and employer-initiated unpaid vacation accounted more than $16 \%$ of the manning table, with an average figure accounting for $6.4 \%$ of the manning table. These employment manage- ment mechanisms allow enterprises and organizations to retain human resources amid uncertainty regarding the short-term development.

Given an unprecedentedly slow economic development growth rates during January over July, the Ministry of Economic Development of Russia made another adjustments to forecast values of the principal macro indicators for 2013: forecast GDP growth rate is lowered down to $1.8 \%$ in annual terms (-0.6 p.p.), capital investments to $2.5 \%$ (-2.1 p.p.), and retail sales turnover to $4.2 \%$ (-0.1 p.p.). Industrial production growth rate is estimated at $100.7 \%$ in the newly updated forecast against previously forecasted 102.0-103.7\%. Given such growth rates in the real sector of economy, the new version of forecast contains estimates of higher growth in real personal income to $103.4 \%$ (+0.4 p.p.) and real wages to $106.2 \%$ (+1.7 p.p.). Under the circumstances, one should expect reduction in revenues and profit in the economy, which would constrict acceleration potential of economic development growth rates in the near term. The situation has been aggravated by a forecast 2.3 -fold annual capital outflow, up to $\$ 70 b n$. 